Research, part of a Special Feature on Do we need new management paradigms to achieve sustainability in tropical forests?

\title{
Integrating Ecosystem Management, Protected Areas, and Mammal Conservation in the Brazilian Amazon
}

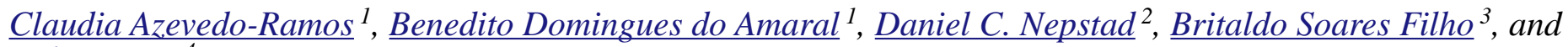 \\ Robert Nasi $^{4}$
}

\begin{abstract}
The Amazon forest has been converted to a matrix of pristine and modified habitats. Landscape-scale biodiversity conservation requires an understanding of species' distributions over this matrix to guarantee both effective protection and use for present and future generations. In this study, we evaluated how much of the existing and future planned protected areas (PAs) would be contributing to the conservation of Brazilian Amazon mammals $(N=399)$, including threatened species $(N=51)$. Currently, almost $37 \%$ of Brazilian Amazon is protected and that may increase to $46 \%$ if planned PAs are implemented. In the current PA system, $22 \%$ are indigenous land and $11 \%$ are sustainable use units, e.g., production forests. Only one-fifth of the whole range of mammal species occurring in Brazilian Amazon is actually protected by Brazilian PAs. However, considering only the part of the ranges within the Brazilian Amazon, and therefore under the scope of Brazilian actions, Brazilian PAs assume an important role in the protection of $39 \%$ of mammal distribution ranges, particularly the threatened species (39\%). These results suggest that an integrated network of protected areas among Amazon countries would be necessary to increase their efficiency in mammal conservation. The need for strengthening of the forest sector and good management practices in Brazil appears critical for the maintenance of large extents of forest and species conservation. Under such a scenario, the contribution of developed nations and international agencies must assume an important role for the maintenance and enlargement of the protected area network in Amazon region.
\end{abstract}

Key Words: biodiversity conservation; Brazilian Amazon; distribution ranges; mammal species; protected areas.

\section{INTRODUCTION}

The advance of economic activities and their consequences for Amazon forests have been predicted and disseminated (Nepstad et al. 2001, Margulis 2003, Nepstad et al. 2004). The latest estimate of the deforestation rate for the Brazilian Amazon during the 2003-2004 period was 26,130 $\mathrm{km}^{2}$ (INPE 2005), almost half of the size of Costa Rica. This is the second highest deforestation rate recorded for Brazilian Amazon. Its causes are associated with cattle ranching, agriculture, and land speculation, with strong consequences to biodiversity conservation.

Landscape management and successful conservation strategies requires an understanding of species' distributions, including which species are restricted to protected areas and which could be adequately protected outside these areas. For slowing the advance of deforestation and conserving the high biological diversity of the region, the Brazilian government has, among other initiatives, invested in a network of protected areas on public lands. The Brazilian conservation units are divided in two main categories: areas of integral protection, e.g., parks, biological reserves, and areas for sustainable use, e. g., national forests, extractives reserves, and sustainable development reserves. In the former category, the use or harvest of natural resources for commercial purposes is not allowed. Besides these two types of protected areas, in public lands there 
are also indigenous lands and military areas. Although they are not considered conservation units by Brazilian law they also have restricted use, not been allowed any economical activities. For the purpose of this study, hereafter, conservation units, indigenous land and military areas are collectively called protected areas (PAs). In addition to the existing PAs, future conservation units are planned for the Brazilian Amazon. The Amazon Region Protected Areas (ARPA) project is a Brazilian government initiative for a system of $28.5 \times 10^{6}$ ha of parks and other protected areas, i.e., more than $10 \%$ of the Brazilian Amazon, to be implemented over $10 \mathrm{yr}$ (www.mma.gov.br). ARPA also includes the consolidation of some already existing conservation units. It is coordinated by the Ministry of Environment and executed by the Brazilian Environmental Agency (IBAMA), with support from the World Bank, the World Wildlife Fund (WWF) pilot program for tropical forest protection in Brazil (PPG-7), the Global Environmental Facility (GEF), and the German Aid Agency (KFW).

According to Brazilian law, two of the main objectives of the National System of Conservation Units (SNUC; law 9985 of 18 July 2000) are, (1) the maintenance of biological and genetic resources, and (2) the protection of threatened species. To the best of our knowledge, those objectives have never been evaluated on a large scale for the whole network of protected areas, possibly due to the complexity involved in that operation. This evaluation becomes even more important nowadays as the choice of location and design of new protected areas is to be made and given the fact that, in the past, many protected areas were implemented for political reasons and not for their biological relevance.

In this study, we evaluated how much of the existing protected areas and the future planned areas would be contributing to the conservation of Brazilian Amazon terrestrial mammals. We used mammal distribution ranges as a first proxy for this analysis. Mammals are a well-known group, with reliable geographic information and generally used as flagship species to represent other groups.

\section{METHODS}

We performed a search on mammal occurrences and distribution ranges in Brazilian Amazonia using the NatureServe's InfoNatura databases as baseline (Patterson et al. 2003). Theses databases are a joint effort of the NatureServe, IUCN, and Conservation International, and were generated using published articles, reports, and expert inputs in several workshops. The output was species distribution maps, which are updated at least once a year. The maps provide a conservative estimate of the ranges as the methodology used probably results in an overestimation of the distribution area for some species. However, it is currently the best data available and also has the support and contribution of several mammal experts who participated in the workshops and continue to send their comments to update the databases. Therefore, we used these individual species distribution maps as the starting point of our analyses.

Mammal distribution ranges were superimposed on a map of the Brazilian Amazon and all species with part $(>1 \%)$ or all of their ranges within Brazilian Amazonia were selected. The Brazilian part of the range of selected species was then superimposed on a map of protected areas, and a map of the Amazon Region Protected Areas (ARPA). Subsequently, we recorded the percentage of overlap between species ranges and protected areas. This gave a general estimate of the potential effectiveness of the design, size, and location of protected areas (PAs) in protecting mammal species. We also performed analyses using a subset of these data, evaluating the case of threatened species. The list of threatened mammal species corresponds with the IUCN Red List. In a conservative approach, we also included in our analyses mammals in the "near-threatened" category.

We observed a high degree of overlap among PA boundaries. As there is no agreement related to the real contour of those areas yet, we had to assume an arbitrary criterion to remove these areas of overlap every time that occurred. Therefore, we first identified indigenous land boundaries, i.e., the most abundant, then, discounting areas of overlapping, we identified federal conservation units and, finally, state units. This step was important to avoid measuring the overlap between a mammal range and a PA twice in instances when a PA overlays another PA. 


\section{RESULTS}

Currently, almost $37 \%$ of Brazilian Amazon is protected, when overlapping areas are removed (Fig. 1). Once implemented, the Amazon Region Protected Areas (ARPA) project would increase this percentage to $46 \%$ (Table 1$)$. Indigenous lands $(N$ $=355$ ) occupy almost $21 \%$ of the Brazilian Amazon and are by far the most extensive PA network, followed by federal units, i.e., $9.3 \%$ of the area, state units $(6.6 \%)$. Military areas $(N=20)$ cover only a small portion of the Brazilian Amazon (0.5\%). The current overlap among different types of PAs may causes differences in area varying from $7.5 \%$ for state units to $49 \%$ for military areas (Table 1).

Among federal conservation units $(N=127)$, we distinguished 42 areas of integral protection, i.e., $4.6 \%$ of Brazilian Amazon, and 85 areas of sustainable use $(4.8 \%)$. For state units $(N=196)$, there are 54 areas of integral protection $(0.9 \%)$ and 142 areas of sustainable use (5.6\%).

We recorded 399 mammal species for the entire Brazilian Amazon (Appendix). The overlap of their ranges generated a map, which indicated the areas with potential higher species richness (Fig. 2a). The western Amazon, the region along the Amazon River, and the north of Brazilian Amazon stand out as having the highest species richness. Overlaying PAs and military areas maps and this specie richness map allows a spatial visualization of the contribution of each unit in the conservation of mammal diversity (Fig. 2b-e; see details below).

In many cases, the range of a species exceeded the limits of the Brazilian Amazon and even of the Amazon basin. Therefore, we analyzed the contribution of Brazilian PAs considering this perspective. If we consider the whole distribution of a species, here called "Total range", or only the part their distribution comprising the Amazonia, "Panamazonia", the Brazilian PAs and military areas overlap with $18.7 \%$ and $24 \%$ of species ranges, respectively (Table 2). With ARPA implementation, that percentage may increase to $23 \%$ and $30 \%$, respectively. The number of Brazilian mammal species that have at least a small part of their ranges inside a federal or state unit is considerable $(N=363$ and 353 , respectively). For indigenous land the number of mammals is slightly higher $(N=375)$. However, the mean proportion of their range within those units regarding their distribution in the Brazilian Amazonia is much lower than indigenous land (Table 2). Considering only part of the ranges effectively within the Brazilian Amazon boundaries, on average, 39\% of mammal ranges are already protected within PAs and military areas, with $22 \%$ in indigenous lands, $10 \%$ in federal units, $7 \%$ in state units and $0.3 \%$ in military areas (Table 2). With the implementation of ARPA, almost $47 \%$ of mammal ranges would be included in PAs.

Among federal units, the percentage of overlapping between mammal ranges and areas of sustainable use $(4.78 \%)$ or integral protection $(4.76 \%)$ was very similar. On the other hand, among state units, areas of sustainable use exhibited a higher rate of overlapping $(5.7 \%)$ than integrally protected areas $(1.1 \%)$. Those differences have serious conservation implications as areas of sustainable use may have economic exploitation, e.g., extracting of timber, ecotourism, they demand a closer monitoring of impacts.

A similar approach can be used for subsets of the data or for species of special interest. Using as examples groups of mammals that normally receive the attention of conservationists, we observed that for 79 primate species found in the Brazilian Amazon, $28 \%$ of their whole range is contained within Brazilian PAs (Table 2). Considering just the part of the range within the Brazilian Amazon, almost $42 \%$ of their distribution ranges are included in PAs, i.e., $22 \%$ in indigenous land, $12 \%$ in federal units, and $8 \%$ in state units. The ARPA project would include another $10 \%$ of primate ranges, increasing the percentage of protected range to $53 \%$ (Table 2). Generally, primates have a more restricted range within the Amazon basin than, for instance, cats $(N=8)$, whose ranges overlapped $31 \%$ with PAs and military areas without ARPA and $38 \%$ with ARPA (Table 2). Small mammals, such as marsupials $(N=28)$, had $40 \%$ of their range contained in PAs, e.g., $19.7 \%$ in indigenous land, $8.5 \%$ in federal units, and $12 \%$ in state units. With ARPA (5\%), this rate would increase to $45 \%$ (Table 2).

Overall, a total of 51 Brazilian Amazon mammal species are considered threatened based on IUCN red list, but only 22 species from those are in the Brazilian Environmental Agency (IBAMA) Red List. Considering their whole distribution range, the Brazilian PAs contributed to the protection of $18 \%$, 
Fig. 1. Current and future planned protected areas (ARPA) in the Brazilian Amazon.

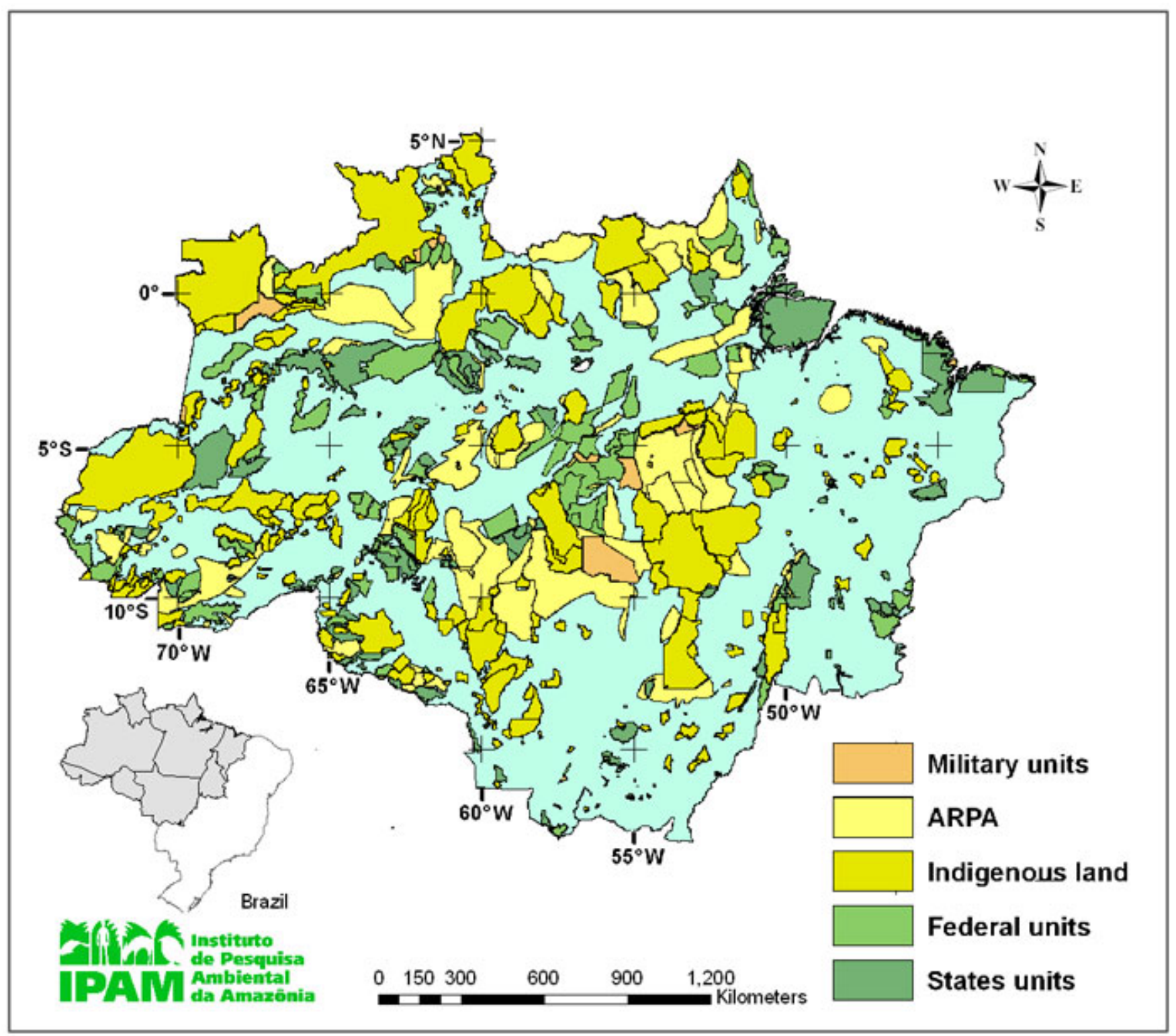

without ARPA, or $21 \%$, with ARPA, of the total species ranges. Taking into account only part of the range within Brazilian Amazon boundaries, 39\%, without ARPA, or $45 \%$, with ARPA, of their ranges overlap with PAs (Table 2).

Considering all Brazilian mammal species, currently 263 species have from $31-50 \%$ of their ranges protected by some kind of PAs (Table 3).
With ARPA implemented, the majority of species $(N=198)$ would have from $41-60 \%$ of their ranges protected (Table 3 ). 
Table 1. Size $\left(\mathrm{km}^{2}\right)$ of protected areas (PAs) in the Brazilian Amazon with and without overlap with other units. $\mathrm{PI}=$ integral protection; $\mathrm{US}=$ sustainable use.

\begin{tabular}{|c|c|c|c|c|c|c|}
\hline & $\begin{array}{c}\text { Total Area } \\
\text { (with overlap) }^{\mathrm{a}}\end{array}$ & $\begin{array}{l}\text { Total area } \\
(\%)\end{array}$ & $\begin{array}{l}\text { Real Area without } \\
\text { overlap }^{\mathrm{b}}\end{array}$ & $\begin{array}{l}\text { Real area } \\
(\%)\end{array}$ & Differences ${ }^{(a-b)}$ & $\begin{array}{l}\text { Differences } \\
\quad(\%)\end{array}$ \\
\hline State PAs & 359905.41 & 7.96 & 332744.77 & 6.56 & 27160.64 & 7.55 \\
\hline IP & 63852.03 & 1.26 & 46179.59 & 0.91 & 17672.44 & 27.68 \\
\hline SU & 296053.38 & 5.83 & 286565.18 & 5.65 & 9488.20 & 3.20 \\
\hline Federal PAs & 571527.75 & 11.26 & 473918.29 & 9.34 & 97609.45 & 17.08 \\
\hline IP & 246113.78 & 4.85 & 231783.75 & 4.57 & 14330.03 & 5.82 \\
\hline SU & 325413.97 & 6.41 & 242134.54 & 4.77 & 83279.42 & 25.59 \\
\hline Indigenous land & 1063694.34 & 20.96 & 106394.34 & 20.96 & 0 & 0.00 \\
\hline Military areas & 51418.08 & 1.01 & 26271.42 & 0.52 & 24946.66 & 48.71 \\
\hline ARPA & 639481.36 & 14.60 & 458813.99 & 9.04 & 180667.37 & 28.25 \\
\hline Total without ARPA & 2046345.59 & 40.32 & 1896628.82 & 37.37 & 149716.76 & 7.32 \\
\hline Total with ARPA & 2685826.95 & 52.92 & 2355442.82 & 46.41 & 330384.13 & 14.30 \\
\hline
\end{tabular}

Note: Total area of Brazilian Amazon $=5,075,032 \mathrm{~km}^{2}$

\section{DISCUSSION}

For Amazon mammal species that occur in Brazil, less than one-fifth of their whole distribution range is protected under Brazilian Protected areas (PA) system. This shows that it is unlikely that only Brazilian PAs could protect Amazon mammal species. An integrated network of protected areas among Amazon countries appears necessary to increase the contribution of these areas to mammal conservation. For that, a similar analysis of this study should be done in neighboring Amazon countries to have a broader perspective of the protection status of some species. On the other hand, considering only the part of the ranges within
Brazilian Amazon, and therefore under the scope of Brazilian actions, Brazilian PAs play an important role in the protection of $40 \%$ of mammal distribution ranges, including the threatened species (39\%).

Indigenous lands, although not officially part of the conservation unit system, offer a great potential for the conservation of mammals, i.e., $22 \%$ of overlapping. As indigenous lands in Brazil occupy an area almost the size of Bolivia, they have a disproportional relevance in the conservation of fauna compared, for instance, to parks, which are 4 times smaller in size. Even though mammals are subjected to hunting in indigenous land, the potentially negative effect of this activity may be 
Fig. 2. Map of richness of mammal ranges $(N=399)$ for Amazonia superimposed on main protected areas: federal conservation units, state conservation units, indigenous land, and Amazon Region Protected Areas (ARPA). The darker the color, the higher the richness.

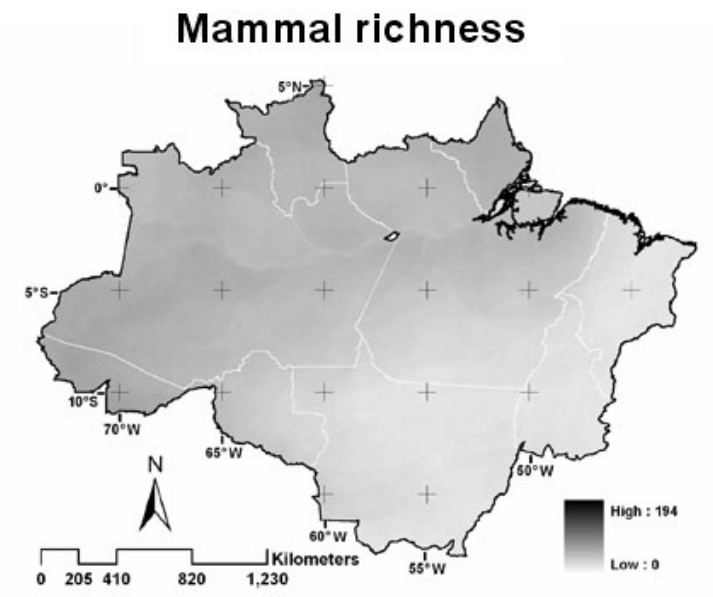

\section{Federal Units}

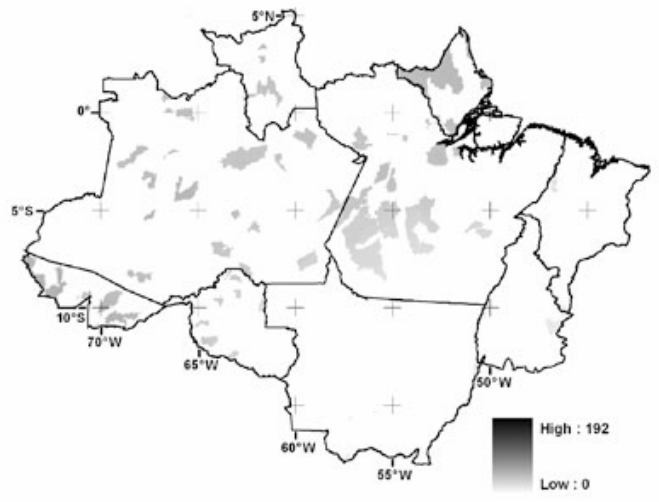

State Units

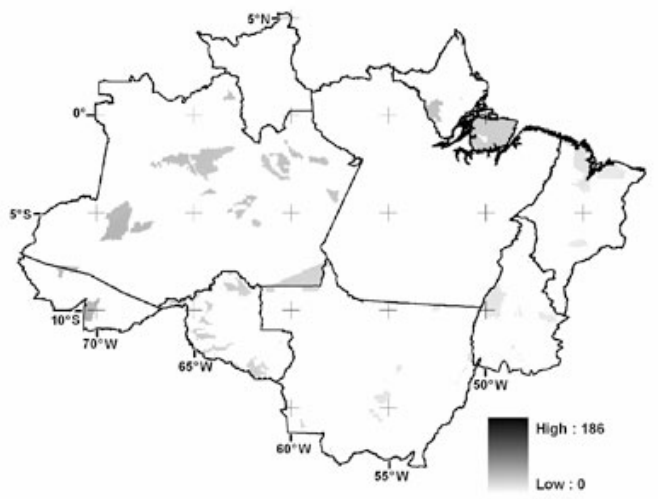

Indigenous Land

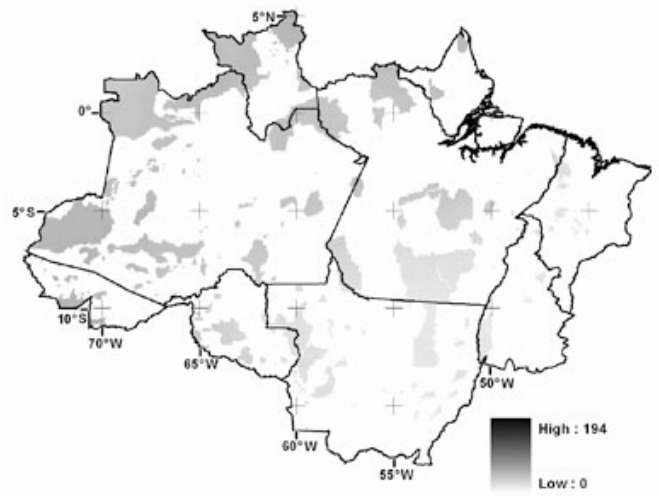

ARPA

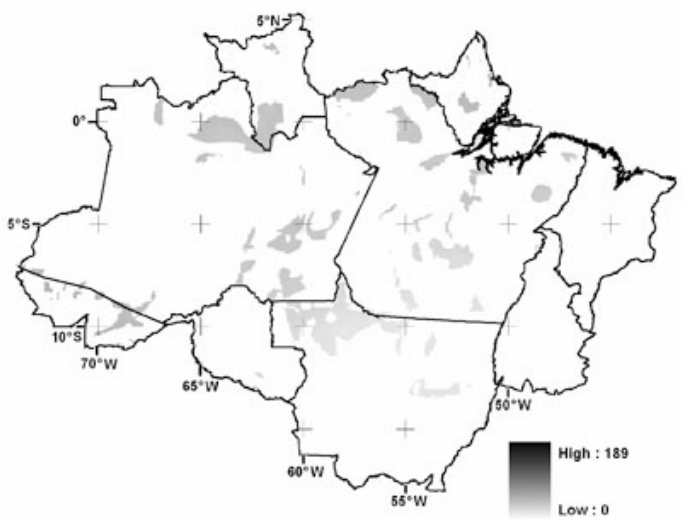


Table 2. Percentage of overlap between mammal ranges and protected areas in the Brazilian Amazon, considering their total range, part of their ranges in Amazonia, i.e., "Panamazonia", and only part of their ranges in the Brazilian Amazon ("Braz. Amaz."). IL = indigenous land; FED = Federal units; ST = State units; $\mathrm{MI}=$ military areas.

\begin{tabular}{|c|c|c|c|c|c|c|c|c|}
\hline Groups & Range & ARPA & IL & FED & ST & MI & $\begin{array}{c}\text { With } \\
\text { ARPA }\end{array}$ & $\begin{array}{c}\text { Without } \\
\text { ARPA }\end{array}$ \\
\hline \multirow{3}{*}{$\begin{array}{l}\text { Total } \\
(N=400)\end{array}$} & Total range & 4.5 & 9.9 & 5.0 & 3.6 & 0.1 & 23.2 & 18.7 \\
\hline & Panamazonia & 5.6 & 13.0 & 6.3 & 4.9 & 0.2 & 30.0 & 24.4 \\
\hline & Braz. Amaz. & 8.1 & 22.1 & 9.8 & 7.2 & 0.3 & 47.4 & 39.4 \\
\hline \multirow{3}{*}{$\begin{array}{l}\text { Primates } \\
(N=79)\end{array}$} & Total range & 8.5 & 14.0 & 7.9 & 5.8 & 0.2 & 36.4 & 27.9 \\
\hline & Panamazonia & 8.7 & 14.6 & 8.06 & 6.2 & 0.2 & 37.7 & 29.1 \\
\hline & Braz. Amaz. & 10.5 & 21.8 & 12.1 & 8.3 & 0.2 & 52.8 & 42.4 \\
\hline \multirow{3}{*}{$\begin{array}{l}\text { Cats } \\
(N=8)\end{array}$} & Total range & 2.2 & 5.2 & 2.3 & 3.4 & 0.1 & 13.3 & 11.1 \\
\hline & Panamazonia & 4.7 & 11.0 & 4.8 & 4.8 & 0.3 & 25.6 & 20.9 \\
\hline & Braz. Amaz. & 6.8 & 16.5 & 6.9 & 7.1 & 0.4 & 37.7 & 30.9 \\
\hline \multirow{3}{*}{$\begin{array}{l}\text { Marsupials } \\
(N=28)\end{array}$} & Total range & 2.5 & 8.9 & 3.8 & 7.4 & 0.1 & 22.7 & 20.1 \\
\hline & Panamazonia & 3.3 & 11.2 & 5.0 & 9.2 & 0.1 & 28.8 & 25.5 \\
\hline & Braz. Amaz. & 5.0 & 19.7 & 8.0 & 11.7 & 0.2 & 45.1 & 40.1 \\
\hline \multirow{3}{*}{$\begin{array}{l}\text { Threatened species } \\
(N=51)\end{array}$} & Total range & 2.9 & 7.8 & 3.1 & 6.7 & 0.1 & 20.7 & 17.7 \\
\hline & Panamazonia & 3.9 & 11.3 & 4.2 & 8.3 & 0.2 & 27.9 & 24.0 \\
\hline & Braz. Amaz. & 5.6 & 20.4 & 6.8 & 11.7 & 0.2 & 44.8 & 39.1 \\
\hline
\end{tabular}

minimized given the size of these lands compared to the low density of the indigenous population. That may allow a rapid recovery of game species although we do need more research on this subject. A recent study showed no difference regarding the inhibition of deforestation or fire between indigenous land and parks in Brazilian Amazon (Nepstad et al. 2006). The authors also concluded that as indigenous lands are usually located in areas of agricultural frontier expansion while parks are located in remote areas, the former would have an important role as barriers for deforestation and forest fires.

Federal and state units together include only $17 \%$ of the mammal ranges. That may be not enough for effective protection. Overall, sustainable use category, that which allows the performance of economic activities within its boundaries, comprises the largest amount of area (11\%) compared to integral protection $(6 \%)$, indicating the relevance of a good forest management to avoid 
Table 3. Number of mammal species in different categories of range overlap with protected areas.

\begin{tabular}{lcc}
\hline \hline Range overlap (\%) & $\begin{array}{c}\text { \# species } \\
\text { without ARPA }\end{array}$ & $\begin{array}{c}\text { \# species } \\
\text { with ARPA }\end{array}$ \\
\hline $0-0.9 \%$ & 3 & 2 \\
$1-10 \%$ & 10 & 8 \\
$11-20 \%$ & 32 & 12 \\
$21-30 \%$ & 35 & 26 \\
$31-40 \%$ & 154 & 37 \\
$41-50 \%$ & 109 & 154 \\
$51-60 \%$ & 25 & 88 \\
$61-70 \%$ & 14 & 31 \\
$71-80 \%$ & 4 & 12 \\
$81-90 \%$ & 2 & 6 \\
$91-100 \%$ & 8 & 9
\end{tabular}

species losses in those areas. Among these units, state units would be the most fragile regarding conservation not only because the sustainable use category occurs in higher number and size, but also because within this category, the models of use allow large economic and demographic use, e.g., "APA" area of environmental protection, but which may include an urban area. Also, it worth to notice that state units comprises a higher portion of threatened species ranges within their areas compared to federal units.

With the Brazilian government effort to increase PAs from $37-46 \%$ of Brazilian Amazon area in the next $10 \mathrm{yr}$, the protected fraction of mammal ranges would be 1.2 times larger than what already exists. That alone would already be extremely positive, but there is a chance that with the same size but better design and location of those areas, the biological relevance of these additional areas could be improved. For instance, detailed evaluations of other parameters, such as other taxa, the presence of species of interest, areas of higher richness, relevant environmental variables, and proximity to human communities may be used to decide between different types of categories of protection. Additionally, it would be necessary to consider the impoverishment of forests due to logging (e.g., Azevedo-Ramos et al. 2005, 2006) and hunting within and outside the protected boundaries. Those actions would probably result in better conservation of an important fraction of Amazon fauna. The evaluation of these effects was beyond the objectives of this study, but they certainly need to be investigated for a better estimate of the status of protection of mammals in PAs and to better determine alternatives to mitigate the negative impacts.

Several parks, reserves, and indigenous land were analyzed for the direct and indirect effects of land use outside their boundaries. For instance, disturbances outside the protected limits can reduce by $15 \%$ the rainfall inside parks in tropical Africa (Roy et al. 2005). Plant richness of tropical forests is highly correlated to precipitation (Givnish 1999, Taplin and Lovett 2003) and plants have great influence on the richness of other taxa (Kay et al. 
1997, Andrews and O'Brian 2000). Therefore, an evaluation of the influence of the surroundings on the ecosystem health of PAs is necessary to better guarantee the protection of biodiversity inside conservation units and indigenous land. For that and also to guarantee a largescale, integrated approach, it would be necessary to adopt a landscape approach as new management paradigm for PAs.

In a recent study that evaluated future scenarios of development for Panamazonia, we estimated that keeping the current trend of relatively little governance and increasing the infrastructure network, i.e., mainly roads, $30 \%$ of mammal species $(N=382)$ would have less than $60 \%$ of their range remaining due to accumulated deforestation until 2050 (Soares-Filho et al. 2006). The fact that currently, without ARPA, almost $61 \%$ of mammal ranges occur outside protected areas, reinforces the necessity of valuing forestry activities outside those boundaries that guarantee larger vegetation cover, larger and better ecological corridors, and genetic flux among population. With the implementation of ARPA, we would have $47 \%$ of mammal ranges within PAs. That demonstrates the importance of ARPA for a better protection of this group, but also indicates that actions that increase governance and better land use outside these units are of extreme importance to maximize the conservation of this animal group and biodiversity in general. Environmentalists and the Brazilian government should keep this in mind, to distribute their efforts and resources proportionally.

The conservation of the current $37 \%$ or future $46 \%$ of Brazilian Amazon Forest within PAs is a monumental effort for a developing country like Brazil. The role of large forest areas, like the Amazon Basin, is of undeniable importance for global climate and the conservation of genetic resources. Deforestation in the Brazilian Amazon releases about $200 \times 10^{6}$ tons of $\mathrm{C} / \mathrm{yr}$, that is, $2-3 \%$ of total human emissions (Houghlton 2001). This increases to $10 \%$, if emissions from logging and forest fire are included (Nepstad et al. 1999). Additionally, one third of the global biodiversity is in Amazonia.

In this sense, the strengthening of the forest sector in Brazil as an economical alternative to ranching and agriculture becomes critical for the maintenance of large extents of forest. Also, new economic mechanisms taking advantages of the carbon market, such as compensated reduction of deforestation (Moutinho and Schwartzman 2005, Santilli et al. 2005), should not be underestimated as new economic sources for conservation. Of equal importance is the contribution of developed nations and international agencies for the maintenance and enlargement of these protected area networks.

Responses to this article can be read online at: http://www.ecologyandsociety.org/voll1/iss2/art17/responses/

\section{Acknowledgments:}

This study was funded by research grants from Gordon and Betty Moore Foundation, USAID, European Commission and a CIFOR's grant. We thank Claudia Stickler for reviewing the English version of the manuscript.

\section{LITERATURE CITED}

Andrews, P., and E. M. O'Brian. 2000. Climate, vegetation, and predictable gradients in mammal species richness in southern Africa. Journal of Zoology 251:205-231.

Azevedo-Ramos, C., O. de Carvalho Jr., R. Nasi. 2005. Animal indicators: a tool for assessing biotic integrity after logging in tropical forests? Instituto de Pesquisa Ambiental da Amazonia. Brasília, Brazil.

Azevedo-Ramos, C. O. de Carvalho Jr., and B. D. do Amaral. Short-term effect of reduced-impact logging on fauna in eastern Amazonia. Forest Ecology and Management 232:(1-3):26-35.

InfoNatura. 2005. Birds, mammals, and amphibians of Latin America [web application]. Version 4.0. NatureServe, Arlington, Virginia, USA. Available online at: http://www.natureserve. org/infonatura.

Instituto Nacional de Pesquisas Espaciais (INPE). 2005. Monitoramento da floresta amazônica brasileira por satélite: Projeto Prodes. Available online at: http://www.obt.inpe.br/prodes/

Givnish, T. J. 1999. On the causes of gradients in 
tropical tree diversity. Journal of Ecology 87:193-210.

Houghton, R. A., D. L. Skole, C. A. Nobre, J. L. Hackler, K. T. Lawrence, and W. H. Chomentowski. 2000. Annual fluxes of carbon from deforestation and regrowth in the Brazilian Amazon. Nature 403:301-304.

Kay, R. F., R. H. Madden, C. Van Schaik, and D. Higdon. 1997. Primate species richness is determined by plant productivity: implications for conservation. Proceedings of the Natural Academy of Sciences 94:13023-13027.

Margulis, S. 2003. Causes of deforestation of the Brazilian Amazon. World Bank Working Papers. Washington, D.C., USA.

Moutinho, P., and S. Schwartzman. 2005. Tropical deforestation and climate change. Instituto de Pesquisa Ambiental da Amazônia, Belém, Brazil.

Nepstad, D. C., A. Veríssimo, A. Alencar, C. Nobre, E. Lima, P. Lefebvre, P. Schlesinger, C. Potter, P. Moutinho, E. Mendoza, M. Cochrane, and V. Brooks. 1999. Large-scale impoverishment of Amazonian forests by logging and fire. Nature 398:505-8.

Nepstad, D. C., G. Carvalho, A. C. Barros, A. Alencar, J. P. Capobianco, J. Bishop, P. Moutinho, P. Lefebvre, U. L. Silva Jr., and E. Prins. 2001. Road paving, fire, regime feedbacks, and the future of Amazon forests. Forest Ecology and Management 154:395-407.

Nepstad, D. C., C. Azevedo-Ramos, E. Lima, D. McGrath, C. Pereira, and F. Merry. 2004. Managing the Amazon timber industry. Conservation Biology 18(2):575-577.

Nepstad, D. C., S. Schwartzman, M. Santilli, D. Ray, P. Schlesinger, P. Lefebvre, A. Alencar, E. Prinz, G. Fiske, and A. Rolla. 2006. Inhibition of Amazon deforestation and fire by parks and indigenous reserve. Conservation Biology 20 (1):65-73.

Patterson, B. D., G. Ceballos, W. Secherest, M. F. Tognelli, T. Brooks, L. Luna, P. Ortega, I. Salazar, and B. E. Young. 2003. Digital distribution maps of the mammals of the western hemisphere. Version 1.0. NatureServe, Arlington, Virginia, USA.

Santilli, M., P. Moutinho, S. Schwartzman, D. C. Nepstad, L. Curran, and C. Nobre. 2005. Tropical deforestation and the Kyoto Protocol: an editorial essay. Climatic Change 71:267-276.

Soares-Filho, B. S., D. Nepstad, L. Curran, E. Voll, G. Cerqueira, R. A. Garcia, C. AzevedoRamos, A. Mcdonald, A.; Lefebvre, and P. Schlesinger. 2006. Modeling conservation in the Amazon Basin. Nature 440:520-523.

Roy, S. B., P. D. Wash, and J. W. Lichstein. 2005. Can logging in equatorial Africa affect adjacent parks? Ecology and Society 10(1):6 [online] URL: http://www.ecologyandsociety.org/vol10/iss 1/art6/

Taplin, J. R. D., and J. C. Lovett. 2003. Can we predict centers of plant species richness and rarity from environmental variables in sub-Saharan Africa? Botanical Journal of Linnean Society 142:187-197. 
APPENDIX. List of Brazilian Amazon mammals used for the analyses.

\begin{tabular}{|c|c|c|}
\hline Order & Family & Scientific Name \\
\hline Artiodactyla & Cervidae & Blastocerus dichotomus \\
\hline Artiodactyla & Cervidae & Mazama americana \\
\hline Artiodactyla & Cervidae & Mazama gouazoubira \\
\hline Artiodactyla & Cervidae & Odocoileus virginianus \\
\hline Artiodactyla & Cervidae & Ozotoceros bezoarticus \\
\hline Artiodactyla & Tayassuidae & Pecari tajacu \\
\hline Artiodactyla & Tayassuidae & Tayassu pecari \\
\hline Carnivora & Canidae & Atelocynus microtis \\
\hline Carnivora & Canidae & Cerdocyon thous \\
\hline Carnivora & Canidae & Chrysocyon brachyurus \\
\hline Carnivora & Canidae & Pseudalopex vetulus \\
\hline Carnivora & Canidae & Speothos venaticus \\
\hline Carnivora & Felidae & Herpailurus yaguarondi \\
\hline Carnivora & Felidae & Leopardus pardalis \\
\hline Carnivora & Felidae & Leopardus tigrinus \\
\hline Carnivora & Felidae & Leopardus wiedii \\
\hline Carnivora & Felidae & Lynchailurus braccatus \\
\hline Carnivora & Felidae & Panthera onca \\
\hline Carnivora & Felidae & Puma concolor \\
\hline Carnivora & Mustelidae & Eira barbara \\
\hline Carnivora & Mustelidae & Galictis vittata \\
\hline Carnivora & Mustelidae & Lontra longicaudis \\
\hline Carnivora & Mustelidae & Mustela africana \\
\hline Carnivora & Mustelidae & Pteronura brasiliensis \\
\hline Carnivora & Procyonidae & Bassaricyon beddardi \\
\hline Carnivora & Procyonidae & Nasua nasua \\
\hline
\end{tabular}




\begin{tabular}{|c|c|c|}
\hline Carnivora & Procyonidae & Potos flavus \\
\hline Carnivora & Procyonidae & Procyon cancrivorus \\
\hline Chiroptera & Emballonuridae & Centronycteris maximiliani \\
\hline Chiroptera & Emballonuridae & Cormura brevirostris \\
\hline Chiroptera & Emballonuridae & Cyttarops alecto \\
\hline Chiroptera & Emballonuridae & Diclidurus albus \\
\hline Chiroptera & Emballonuridae & Diclidurus ingens \\
\hline Chiroptera & Emballonuridae & Diclidurus isabellus \\
\hline Chiroptera & Emballonuridae & Diclidurus scutatus \\
\hline Chiroptera & Emballonuridae & Peropteryx kappleri \\
\hline Chiroptera & Emballonuridae & Peropteryx macrotis \\
\hline Chiroptera & Emballonuridae & Rhynchonycteris naso \\
\hline Chiroptera & Emballonuridae & Saccopteryx bilineata \\
\hline Chiroptera & Emballonuridae & Saccopteryx canescens \\
\hline Chiroptera & Emballonuridae & Saccopteryx gymnura \\
\hline Chiroptera & Emballonuridae & Saccopteryx leptura \\
\hline Chiroptera & Furipteridae & Furipterus horrens \\
\hline Chiroptera & Molossidae & Cynomops abrasus \\
\hline Chiroptera & Molossidae & Cynomops paranus \\
\hline Chiroptera & Molossidae & Cynomops planirostris \\
\hline Chiroptera & Molossidae & Eumops auripendulus \\
\hline Chiroptera & Molossidae & Eumops bonariensis \\
\hline Chiroptera & Molossidae & Eumops glaucinus \\
\hline Chiroptera & Molossidae & Eumops hansae \\
\hline Chiroptera & Molossidae & Eumops perotis \\
\hline Chiroptera & Molossidae & Eumops trumbulli \\
\hline Chiroptera & Molossidae & Molossops neglectus \\
\hline Chiroptera & Molossidae & Molossops temminckii \\
\hline Chiroptera & Molossidae & Molossus bondae \\
\hline
\end{tabular}




\begin{tabular}{|c|c|c|}
\hline Chiroptera & Molossidae & Molossus molossus \\
\hline Chiroptera & Molossidae & Molossus rufus \\
\hline Chiroptera & Molossidae & Neoplatymops mattogrossensis \\
\hline Chiroptera & Molossidae & Nyctinomops aurispinosus \\
\hline Chiroptera & Molossidae & Nyctinomops laticaudatus \\
\hline Chiroptera & Molossidae & Nyctinomops macrotis \\
\hline Chiroptera & Molossidae & Promops centralis \\
\hline Chiroptera & Molossidae & Promops nasutus \\
\hline Chiroptera & Mormoopidae & Pteronotus davyi \\
\hline Chiroptera & Mormoopidae & Pteronotus gymnonotus \\
\hline Chiroptera & Mormoopidae & Pteronotus parnellii \\
\hline Chiroptera & Mormoopidae & Pteronotus personatus \\
\hline Chiroptera & Natalidae & Natalus stramineus \\
\hline Chiroptera & Noctilionidae & Noctilio albiventris \\
\hline Chiroptera & Noctilionidae & Noctilio leporinus \\
\hline Chiroptera & Phyllostomidae & Ametrida centurio \\
\hline Chiroptera & Phyllostomidae & Anoura caudifer \\
\hline Chiroptera & Phyllostomidae & Anoura geoffroyi \\
\hline Chiroptera & Phyllostomidae & Artibeus concolor \\
\hline Chiroptera & Phyllostomidae & Artibeus jamaicensis \\
\hline Chiroptera & Phyllostomidae & Artibeus lituratus \\
\hline Chiroptera & Phyllostomidae & Artibeus obscurus \\
\hline Chiroptera & Phyllostomidae & Carollia brevicauda \\
\hline Chiroptera & Phyllostomidae & Carollia castanea \\
\hline Chiroptera & Phyllostomidae & Carollia perspicillata \\
\hline Chiroptera & Phyllostomidae & Chiroderma salvini \\
\hline Chiroptera & Phyllostomidae & Chiroderma trinitatum \\
\hline Chiroptera & Phyllostomidae & Chiroderma villosum \\
\hline Chiroptera & Phyllostomidae & Choeroniscus godmani \\
\hline
\end{tabular}


Chiroptera

Chiroptera

Chiroptera

Chiroptera

Chiroptera

Chiroptera

Chiroptera

Chiroptera

Chiroptera

Chiroptera

Chiroptera

Chiroptera

Chiroptera

Chiroptera

Chiroptera

Chiroptera

Chiroptera

Chiroptera

Chiroptera

Chiroptera

Chiroptera

Chiroptera

Chiroptera

Chiroptera

Chiroptera

Chiroptera

Chiroptera

Chiroptera

Chiroptera
Phyllostomidae

Phyllostomidae

Phyllostomidae

Phyllostomidae

Phyllostomidae

Phyllostomidae

Phyllostomidae

Phyllostomidae

Phyllostomidae

Phyllostomidae

Phyllostomidae

Phyllostomidae

Phyllostomidae

Phyllostomidae

Phyllostomidae

Phyllostomidae

Phyllostomidae

Phyllostomidae

Phyllostomidae

Phyllostomidae

Phyllostomidae

Phyllostomidae

Phyllostomidae

Phyllostomidae

Phyllostomidae

Phyllostomidae

Phyllostomidae

Phyllostomidae

Phyllostomidae
Choeroniscus minor

Chrotopterus auritus

Dermanura anderseni

Dermanura cinerea

Dermanura glauca

Dermanura gnoma

Dermanura phaeotis

Desmodus rotundus

Diaemus youngi

Diphylla ecaudata

Ectophylla macconnelli

Glossophaga commissarisi

Glossophaga longirostris

Glossophaga soricina

Glyphonycteris daviesi

Glyphonycteris sylvestris

Lampronycteris brachyotis

Lichonycteris obscura

Lionycteris spurrelli

Lonchophylla handleyi

Lonchophylla thomasi

Lonchorhina aurita

Lonchorhina inusitata

Macrophyllum macrophyllum

Micronycteris behnii

Micronycteris hirsuta

Micronycteris megalotis

Micronycteris microtis

Micronycteris schmidtorum 
Chiroptera

Chiroptera

Chiroptera

Chiroptera

Chiroptera

Chiroptera

Chiroptera

Chiroptera

Chiroptera

Chiroptera

Chiroptera

Chiroptera

Chiroptera

Chiroptera

Chiroptera

Chiroptera

Chiroptera

Chiroptera

Chiroptera

Chiroptera

Chiroptera

Chiroptera

Chiroptera

Chiroptera

Chiroptera

Chiroptera

Chiroptera

Chiroptera

Chiroptera
Phyllostomidae

Phyllostomidae

Phyllostomidae

Phyllostomidae

Phyllostomidae

Phyllostomidae

Phyllostomidae

Phyllostomidae

Phyllostomidae

Phyllostomidae

Phyllostomidae

Phyllostomidae

Phyllostomidae

Phyllostomidae

Phyllostomidae

Phyllostomidae

Phyllostomidae

Phyllostomidae

Phyllostomidae

Phyllostomidae

Phyllostomidae

Phyllostomidae

Phyllostomidae

Phyllostomidae

Phyllostomidae

Phyllostomidae

Phyllostomidae

Phyllostomidae

Phyllostomidae
Mimon bennettii

Mimon crenulatum

Phylloderma stenops

Phyllostomus discolor

Phyllostomus elongatus

Phyllostomus hastatus

Phyllostomus latifolius

Platyrrhinus brachycephalus

Platyrrhinus helleri

Platyrrhinus infuscus

Platyrrhinus lineatus

Platyrrhinus recifinus

Pygoderma bilabiatum

Rhinophylla fischerae

Rhinophylla pumilio

Scleronycteris ega

Sphaeronycteris toxophyllum

Sturnira lilium

Sturnira tildae

Tonatia brasiliense

Tonatia carrikeri

Tonatia saurophila

Tonatia schulzi

Tonatia silvicola

Trachops cirrhosus

Trinycteris nicefori

Uroderma bilobatum

Uroderma magnirostrum

Vampyressa bidens 


\begin{tabular}{|c|c|c|}
\hline Chiroptera & Phyllostomidae & Vampyressa pusilla \\
\hline Chiroptera & Phyllostomidae & Vampyrodes caraccioli \\
\hline Chiroptera & Phyllostomidae & Vampyrum spectrum \\
\hline Chiroptera & Thyropteridae & Thyroptera discifera \\
\hline Chiroptera & Thyropteridae & Thyroptera lavali \\
\hline Chiroptera & Thyropteridae & Thyroptera tricolor \\
\hline Chiroptera & Vespertilionidae & Eptesicus brasiliensis \\
\hline Chiroptera & Vespertilionidae & Eptesicus furinalis \\
\hline Chiroptera & Vespertilionidae & Eptesicus fuscus \\
\hline Chiroptera & Vespertilionidae & Histiotus velatus \\
\hline Chiroptera & Vespertilionidae & Lasiurus blossevillei \\
\hline Chiroptera & Vespertilionidae & Lasiurus cinereus \\
\hline Chiroptera & Vespertilionidae & Lasiurus ega \\
\hline Chiroptera & Vespertilionidae & Myotis albescens \\
\hline Chiroptera & Vespertilionidae & Myotis nigricans \\
\hline Chiroptera & Vespertilionidae & Myotis riparius \\
\hline Chiroptera & Vespertilionidae & Myotis simus \\
\hline Chiroptera & Vespertilionidae & Rhogeessa tumida \\
\hline Didelphimorphia & Caluromyidae & Caluromys lanatus \\
\hline Didelphimorphia & Caluromyidae & Caluromys philander \\
\hline Didelphimorphia & Caluromyidae & Caluromysiops irrupta \\
\hline Didelphimorphia & Didelphidae & Chironectes minimus \\
\hline Didelphimorphia & Didelphidae & Didelphis albiventris \\
\hline Didelphimorphia & Didelphidae & Didelphis marsupialis \\
\hline Didelphimorphia & Didelphidae & Philander andersoni \\
\hline Didelphimorphia & Didelphidae & Philander mcilhennyi \\
\hline Didelphimorphia & Didelphidae & Philander opossum \\
\hline Didelphimorphia & Glironiidae & Glironia venusta \\
\hline Didelphimorphia & Marmosidae & Gracilinanus agilis \\
\hline
\end{tabular}


Didelphimorphia

Didelphimorphia

Didelphimorphia

Didelphimorphia

Didelphimorphia

Didelphimorphia

Didelphimorphia

Didelphimorphia

Didelphimorphia

Didelphimorphia

Didelphimorphia

Didelphimorphia

Didelphimorphia

Didelphimorphia

Didelphimorphia

Didelphimorphia

Didelphimorphia

Didelphimorphia

Didelphimorphia

Lagomorpha

Perissodactyla

Primates

Primates

Primates

Primates

Primates

Primates

Primates

Primates
Marmosidae

Marmosidae

Marmosidae

Marmosidae

Marmosidae

Marmosidae

Marmosidae

Marmosidae

Marmosidae

Marmosidae

Marmosidae

Marmosidae

Marmosidae

Marmosidae

Marmosidae

Marmosidae

Marmosidae

Marmosidae

Marmosidae

Leporidae

Tapiridae

Aotidae

Aotidae

Aotidae

Aotidae

Aotidae

Atelidae

Atelidae

Atelidae
Gracilinanus emiliae

Marmosa lepida

Marmosa murina

Marmosops impavidus

Marmosops neblina

Marmosops noctivagus

Marmosops parvidens

Marmosops pinheiroi

Metachirus nudicaudatus

Micoureus constantiae

Micoureus demerarae

Micoureus regina

Monodelphis americana

Monodelphis brevicaudata

Monodelphis domestica

Monodelphis emiliae

Monodelphis kunsi

Monodelphis maraxina

Thylamys velutinus

Sylvilagus brasiliensis

Tapirus terrestris

Aotus infulatus

Aotus nancymaae

Aotus nigriceps

Aotus trivirgatus

Aotus vociferans

Alouatta belzebul

Alouatta caraya

Alouatta nigerrima 


\begin{tabular}{|c|c|c|}
\hline Primates & Atelidae & Alouatta seniculus \\
\hline Primates & Atelidae & Alouatta ululata \\
\hline Primates & Atelidae & Ateles belzebuth \\
\hline Primates & Atelidae & Ateles chamek \\
\hline Primates & Atelidae & Ateles marginatus \\
\hline Primates & Atelidae & Ateles paniscus \\
\hline Primates & Atelidae & Lagothrix cana \\
\hline Primates & Atelidae & Lagothrix lagothricha \\
\hline Primates & Atelidae & Lagothrix poeppigii \\
\hline Primates & Callitrichidae & Callimico goeldii \\
\hline Primates & Callitrichidae & Callithrix penicillata \\
\hline Primates & Callitrichidae & Cebuella pygmaea \\
\hline Primates & Callitrichidae & Mico acariensis \\
\hline Primates & Callitrichidae & Mico argentatus \\
\hline Primates & Callitrichidae & Mico chrysoleucus \\
\hline Primates & Callitrichidae & Mico emiliae \\
\hline Primates & Callitrichidae & Mico humeralifer \\
\hline Primates & Callitrichidae & Mico intermedius \\
\hline Primates & Callitrichidae & Mico leисірре \\
\hline Primates & Callitrichidae & Mico manicorensis \\
\hline Primates & Callitrichidae & Mico marcai \\
\hline Primates & Callitrichidae & Mico mauesi \\
\hline Primates & Callitrichidae & Mico melanurus \\
\hline Primates & Callitrichidae & Mico nigriceps \\
\hline Primates & Callitrichidae & Mico saterei \\
\hline Primates & Callitrichidae & Saguinus bicolor \\
\hline Primates & Callitrichidae & Saguinus fuscicollis \\
\hline Primates & Callitrichidae & Saguinus imperator \\
\hline Primates & Callitrichidae & Saguinus inustus \\
\hline
\end{tabular}




\begin{tabular}{|c|c|c|}
\hline Primates & Callitrichidae & Saguinus labiatus \\
\hline Primates & Callitrichidae & Saguinus martinsi \\
\hline Primates & Callitrichidae & Saguinus midas \\
\hline Primates & Callitrichidae & Saguinus mystax \\
\hline Primates & Callitrichidae & Saguinus niger \\
\hline Primates & Callitrichidae & Saguinus nigricollis \\
\hline Primates & Cebidae & Cebus albifrons \\
\hline Primates & Cebidae & Cebus apella \\
\hline Primates & Cebidae & Cebus kaapori \\
\hline Primates & Cebidae & Cebus libidinosus \\
\hline Primates & Cebidae & Cebus macrocephalus \\
\hline Primates & Cebidae & Cebus olivaceus \\
\hline Primates & Cebidae & Saimiri boliviensis \\
\hline Primates & Cebidae & Saimiri sciureus \\
\hline Primates & Cebidae & Saimiri ustus \\
\hline Primates & Cebidae & Saimiri vanzolinii \\
\hline Primates & Pitheciidae & Cacajao calvus \\
\hline Primates & Pitheciidae & Cacajao melanocephalus \\
\hline Primates & Pitheciidae & Callicebus baptista \\
\hline Primates & Pitheciidae & Callicebus bernhardi \\
\hline Primates & Pitheciidae & Callicebus brunneus \\
\hline Primates & Pitheciidae & Callicebus caligatus \\
\hline Primates & Pitheciidae & Callicebus cinerascens \\
\hline Primates & Pitheciidae & Callicebus cupreus \\
\hline Primates & Pitheciidae & Callicebus dubius \\
\hline Primates & Pitheciidae & Callicebus hoffmannsi \\
\hline Primates & Pitheciidae & Callicebus lucifer \\
\hline Primates & Pitheciidae & Callicebus lugens \\
\hline Primates & Pitheciidae & Callicebus moloch \\
\hline
\end{tabular}




\begin{tabular}{|c|c|c|}
\hline Primates & Pitheciidae & Callicebus purinus \\
\hline Primates & Pitheciidae & Callicebus regulus \\
\hline Primates & Pitheciidae & Callicebus stephennashi \\
\hline Primates & Pitheciidae & Callicebus torquatus \\
\hline Primates & Pitheciidae & Chiropotes albinasus \\
\hline Primates & Pitheciidae & Chiropotes chiropotes \\
\hline Primates & Pitheciidae & Chiropotes sagulatus \\
\hline Primates & Pitheciidae & Chiropotes satanas \\
\hline Primates & Pitheciidae & Chiropotes utahicki \\
\hline Primates & Pitheciidae & Pithecia albicans \\
\hline Primates & Pitheciidae & Pithecia irrorata \\
\hline Primates & Pitheciidae & Pithecia monachus \\
\hline Primates & Pitheciidae & Pithecia pithecia \\
\hline Rodentia & Caviidae & Cavia aperea \\
\hline Rodentia & Caviidae & Cavia tschudii \\
\hline Rodentia & Caviidae & Galea flavidens \\
\hline Rodentia & Caviidae & Galea spixii \\
\hline Rodentia & Caviidae & Kerodon rupestris \\
\hline Rodentia & Ctenomyidae & Ctenomys minutus \\
\hline Rodentia & Ctenomyidae & Ctenomys nattereri \\
\hline Rodentia & Cuniculidae & Cuniculus paca \\
\hline Rodentia & Dasyproctidae & Dasyprocta azarae \\
\hline Rodentia & Dasyproctidae & Dasyprocta fuliginosa \\
\hline Rodentia & Dasyproctidae & Dasyprocta leporina \\
\hline Rodentia & Dasyproctidae & Dasyprocta prymnolopha \\
\hline Rodentia & Dasyproctidae & Dasyprocta punctata \\
\hline Rodentia & Dasyproctidae & Myoprocta acouchy \\
\hline Rodentia & Dasyproctidae & Myoprocta exilis \\
\hline Rodentia & Dasyproctidae & Myoprocta pratti \\
\hline
\end{tabular}




\begin{tabular}{|c|c|c|}
\hline Rodentia & Dinomyidae & Dinomys branickii \\
\hline Rodentia & Echimyidae & Carterodon sulcidens \\
\hline Rodentia & Echimyidae & Clyomys laticeps \\
\hline Rodentia & Echimyidae & Dactylomys boliviensis \\
\hline Rodentia & Echimyidae & Dactylomys dactylinus \\
\hline Rodentia & Echimyidae & Echimys chrysurus \\
\hline Rodentia & Echimyidae & Echimys grandis \\
\hline Rodentia & Echimyidae & Isothrix bistriata \\
\hline Rodentia & Echimyidae & Isothrix pagurus \\
\hline Rodentia & Echimyidae & Lonchothrix emiliae \\
\hline Rodentia & Echimyidae & Makalata didelphoides \\
\hline Rodentia & Echimyidae & Makalata macrura \\
\hline Rodentia & Echimyidae & Mesomys hispidus \\
\hline Rodentia & Echimyidae & Mesomys stimulax \\
\hline Rodentia & Echimyidae & Proechimys amphichoricus \\
\hline Rodentia & Echimyidae & Proechimys brevicauda \\
\hline Rodentia & Echimyidae & Proechimys cayennensis \\
\hline Rodentia & Echimyidae & Proechimys cuvieri \\
\hline Rodentia & Echimyidae & Proechimys echinothrix \\
\hline Rodentia & Echimyidae & Proechimys gardneri \\
\hline Rodentia & Echimyidae & Proechimys goeldii \\
\hline Rodentia & Echimyidae & Proechimys hoplomyoides \\
\hline Rodentia & Echimyidae & Proechimys kulinae \\
\hline Rodentia & Echimyidae & Proechimys longicaudatus \\
\hline Rodentia & Echimyidae & Proechimys oris \\
\hline Rodentia & Echimyidae & Proechimys pattoni \\
\hline Rodentia & Echimyidae & Proechimys quadruplicatus \\
\hline Rodentia & Echimyidae & Proechimys roberti \\
\hline Rodentia & Echimyidae & Proechimys semispinosus \\
\hline
\end{tabular}




\begin{tabular}{|c|c|c|}
\hline Rodentia & Echimyidae & Proechimys simonsi \\
\hline Rodentia & Echimyidae & Proechimys steerei \\
\hline Rodentia & Echimyidae & Thrichomys apereoides \\
\hline Rodentia & Erethizontidae & Coendou bicolor \\
\hline Rodentia & Erethizontidae & Coendou melanurus \\
\hline Rodentia & Erethizontidae & Coendou nycthemera \\
\hline Rodentia & Erethizontidae & Coendou prehensilis \\
\hline Rodentia & Erethizontidae & Coendou roosmalenorum \\
\hline Rodentia & Erethizontidae & Coendou spinosus \\
\hline Rodentia & Hydrochaeridae & Hydrochaeris hydrochaeris \\
\hline Rodentia & Muridae & Bolomys urichi \\
\hline Rodentia & Muridae & Calomys callosus \\
\hline Rodentia & Muridae & Holochilus sciureus \\
\hline Rodentia & Muridae & Kunsia tomentosus \\
\hline Rodentia & Muridae & Microryzomys minutus \\
\hline Rodentia & Muridae & Neacomys dubosti \\
\hline Rodentia & Muridae & Neacomys guianae \\
\hline Rodentia & Muridae & Neacomys minutus \\
\hline Rodentia & Muridae & Neacomys musseri \\
\hline Rodentia & Muridae & Neacomys paracou \\
\hline Rodentia & Muridae & Neacomys spinosus \\
\hline Rodentia & Muridae & Neacomys tenuipes \\
\hline Rodentia & Muridae & Necromys lasiurus \\
\hline Rodentia & Muridae & Nectomys squamipes \\
\hline Rodentia & Muridae & Neusticomys venezuelae \\
\hline Rodentia & Muridae & Oecomys auyantepui \\
\hline Rodentia & Muridae & Oecomys bicolor \\
\hline Rodentia & Muridae & Oecomys concolor \\
\hline Rodentia & Muridae & Oecomys mamorae \\
\hline
\end{tabular}




\begin{tabular}{|c|c|c|}
\hline Rodentia & Muridae & Oecomys paricola \\
\hline Rodentia & Muridae & Oecomys rex \\
\hline Rodentia & Muridae & Oecomys roberti \\
\hline Rodentia & Muridae & Oecomys rutilus \\
\hline Rodentia & Muridae & Oecomys trinitatis \\
\hline Rodentia & Muridae & Oligoryzomys chacoensis \\
\hline Rodentia & Muridae & Oligoryzomys fulvescens \\
\hline Rodentia & Muridae & Oligoryzomys microtis \\
\hline Rodentia & Muridae & Oryzomys emmonsae \\
\hline Rodentia & Muridae & Oryzomys macconnelli \\
\hline Rodentia & Muridae & Oryzomys nitidus \\
\hline Rodentia & Muridae & Oryzomys perenensis \\
\hline Rodentia & Muridae & Oryzomys yunganus \\
\hline Rodentia & Muridae & Oxymycterus amazonicus \\
\hline Rodentia & Muridae & Oxymycterus angularis \\
\hline Rodentia & Muridae & Oxymycterus roberti \\
\hline Rodentia & Muridae & Peromyscus leucopus \\
\hline Rodentia & Muridae & Pseudoryzomys simplex \\
\hline Rodentia & Muridae & Rhipidomys gardneri \\
\hline Rodentia & Muridae & Rhipidomys leucodactylus \\
\hline Rodentia & Muridae & Rhipidomys macconnelli \\
\hline Rodentia & Muridae & Rhipidomys mastacalis \\
\hline Rodentia & Muridae & Rhipidomys nitela \\
\hline Rodentia & Muridae & Rhipidomys wetzeli \\
\hline Rodentia & Muridae & Scolomys juruaense \\
\hline Rodentia & Muridae & Sigmodon alstoni \\
\hline Rodentia & Muridae & Thalpomys cerradensis \\
\hline Rodentia & Muridae & Zygodontomys brevicauda \\
\hline Rodentia & Sciuridae & Microsciurus flaviventer \\
\hline
\end{tabular}


Rodentia

Rodentia

Rodentia

Rodentia

Rodentia

Rodentia

Rodentia

Xenarthra

Xenarthra

Xenarthra

Xenarthra

Xenarthra

Xenarthra

Xenarthra

Xenarthra

Xenarthra

Xenarthra

Xenarthra

Xenarthra

Xenarthra

Xenarthra

Xenarthra

Xenarthra

Xenarthra

Xenarthra
Sciuridae

Sciuridae

Sciuridae

Sciuridae

Sciuridae

Sciuridae

Sciuridae

Bradypodidae

Bradypodidae

Dasypodidae

Dasypodidae

Dasypodidae

Dasypodidae

Dasypodidae

Dasypodidae

Dasypodidae

Dasypodidae

Dasypodidae

Dasypodidae

Dasypodidae

Megalonychidae

Megalonychidae

Myrmecophagidae

Myrmecophagidae

Myrmecophagidae
Sciurillus pusillus

Sciurus aestuans

Sciurus alphonsei

Sciurus gilvigularis

Sciurus ignitus

Sciurus igniventris

Sciurus spadiceus

Bradypus tridactylus

Bradypus variegatus

Cabassous chacoensis

Cabassous tatouay

Cabassous unicinctus

Chaetophractus villosus

Dasypus kappleri

Dasypus novemcinctus

Dasypus septemcinctus

Euphractus sexcinctus

Priodontes maximus

Tolypeutes matacus

Tolypeutes tricinctus

Choloepus didactylus

Choloepus hoffmanni

Cyclopes didactylus

Myrmecophaga tridactyla

Tamandua tetradactyla 